\title{
Contributions of the Education through Work for Health Program to the preceptors of Primary Healthcare*
}

\author{
Contribuições do Programa de Educação pelo Trabalho aos \\ preceptores da Atenção Primária à Saúde \\ Contribuciones del Programa de Educación a través del Trabajo \\ a los preceptores de Atención Primaria de Salud
}

How to cite this article:

Velôso RBP, Fernandes JD, Silva RMO, Cordeiro ALAO, Silva GTR, Silva EAL. Contributions of the Education through Work for Health Program to the preceptors of Primary Healthcare. Rev Esc Enferm USP. 2020;54:e03596. doi: https://doi.org/10.1590/S1980-220X2018055903596

\section{Rafaela Braga Pereira Velôso ${ }^{1}$ Josicélia Dumêt Fernandes ${ }^{1}$ Rosana Maria de Oliveira Silva ${ }^{1}$ Ana Lúcia Arcanjo Oliveira} Cordeiro ${ }^{1}$

Gilberto Tadeu Reis da Silva ${ }^{1}$

Elaine Andrade Leal Silva ${ }^{1}$

* Extracted from the dissertation: "Práticas dos preceptores no Programa de Educação pelo Trabalho para a Saúde: (des)integração ensino, serviço e comunidade", Universidade Estadual de Feira de Santana, 2017.

${ }^{1}$ Universidade Federal da Bahia, Escola de Enfermagem, Programa de Pós-Graduação em Enfermagem, Salvador, BA, Brazil.

\begin{abstract}
Objective: To analyze the contributions of the Education through Work for Health Program to the preceptors of Primary Healthcare working in family health units in Feira de Santana, Bahia. Method: A qualitative study conducted with preceptors in the months of March and April 2016, adopting preceptors who had worked in family health units linked to the Program for a minimum period of two years as inclusion criterion. Preceptors on vacation, maternity leave or on leave for different reasons were excluded. The collected data were interpreted based on the content analysis technique. Results: A total of 16 preceptors were interviewed. The Program's contributions to the preceptors were as follows: expanding the perspective on health work, gaining experience in the teaching-learning process and the motivation to continue and search for new studies. Conclusion: The Program enabled preceptors to take a broader look at health work in the context of Primary Healthcare, to gain experience in training processes and motivation to develop new studies, in addition to contributing in a responsible way to the consolidation of the Unified Health System.
\end{abstract}

\section{DESCRIPTORS}

Health Education; Education, Continuing; Professional Practice; Preceptorship; Primary Health Care; Primary Care Nursing. 


\section{INTRODUCTION}

The Education through Work for Health Program (PETHEALTH) is considered an intersectoral action aimed at strengthening strategic areas of the Unified Health System (SUS - Sistema Único de Saúde). The program was established by Interministerial Ordinance No. 421, of March 3, 2010, as a result of the partnership between the Ministry of Health and the Ministry of Education, and aims to offer a learning process through tutorial groups implementing a collective and interdisciplinary nature ${ }^{(1-4)}$.

PET-HEALTH seeks to encourage active interaction of students and teachers of undergraduate health courses with service professionals and the population throughout the teaching-learning process, in line with the real needs of the population. Public or private non-profit Higher Education Institutions can participate in this program in partnership with Municipal and/or State Health Departments from all regions of the country, as selected through public notices published by the Ministry of Health ${ }^{(2,4)}$.

PET-HEALTH is currently in its $9^{\text {th }}$ edition with 120 projects from universities and health departments from all regions of the country, involving more than 6 thousand participants. It lasts for 24 months and has the interprofessional education (IPE) in health theme as its central axis. This proposal involves teaching-service integration with the diversification of practice scenarios in Primary Healthcare and focusing on the population's health needs.

Studies found on PET-HEALTH show that the program stands out for having the "permanent education of the actors involved (health service professionals, students and teachers) and the promotion of intersectoral activities" as one of its axes ${ }^{(5)}$. This proposal contributes to meet the real needs of the population and to strengthen the SUS. Initiatives such as this contribute to the restructuring of health education and to the construction of a new reality in the daily life of the $\operatorname{SUS}^{(3-6)}$.

In other studies regarding an evaluation of the Program, the need to foster teacher development and preceptorship as a key point for operationalizing effective curricular changes stands out. The importance of the service's more active participation in defining and coordinating the actions of the student groups is also emphasized and suggests a collective discussion to redirect health education. It is emphasized that while recognizing the importance of multiprofessional training for primary healthcare, it comes up against the operational difficulty of reconciling meetings between students and teachers from different courses due to the incompatibility of schedules ${ }^{(7-8)}$.

The preceptor stands out when considering the scenario involving PET-HEALTH, because they contribute to integrate teaching, service and community, in addition to strengthening interprofessional work in developing their activities, favoring an experience exchange in the learning space between the groups. The preceptor plays a facilitating role in the teaching-learning process and awakens in the students a desire to better understand professional scenarios and realities ${ }^{(9-11)}$.
Preceptors are professionals with higher education in the health area working in the health service. They have the attribute of "narrowing the distance between theory and practice in training students and present the following functions: guiding, supporting, teaching and sharing experiences which improve student competence" (12). It is believed that "preceptorship contributes to the training process in order to foster the need for permanent training which is adequate and compatible with the health reality of the experienced scenario and collaborates in developing new professionals"(5).

PET-HEALTH provides preceptors with the opportunity to rethink both technical and pedagogical practices given the presence of students in the service. It also favors knowledge of its limitations and importance for the professional training process through acting as mediators and facilitators of learning in the world of work. It is reinforced that the preceptor, being one of the activators of the constant construction of knowledge, establishes mediation through a dialogical relationship with the student, which therefore requires an adequate theoretical and methodological framework ${ }^{(2,7,11)}$.

Therefore, "it is expected that the relationship between the preceptor and the student is horizontal, stimulates the act of thinking and building hypotheses, and that the student discovers the importance of collective work in this relationship"(5). Preceptorship development corresponds to the systematic exercise of monitoring and professional guidance in the health area with a view to educating undergraduate, specialization and resident interns ${ }^{(6-7,10-12)}$.

In this perspective, it is evident that health education has encouraged a modality which promotes integrated and collaborative teamwork among professionals from different areas. These strategies focus on the health needs of users and the population in order to improve the quality of health care ${ }^{(9,12)}$.

In this sense, the object of this study is the contributions of PET-HEALTH to the preceptors of Primary Healthcare. Therefore, the following research question was adopted: What are the contributions of PET-HEALTH to the preceptors of Primary Healthcare?

Thus, the following objective was defined in order to answer this question: to analyze the contributions of PETHEALTH to the preceptors of Primary Healthcare.

\section{METHOD}

\section{Study Design}

This is a qualitative and exploratory study.

\section{Population}

There were 18 professionals intentionally selected who were preceptors of PET-Family Health between the years 2009 and 2014, in the municipality of Feira de Santana, Bahia state, Brazil. However, one professional refused the invitation and another was on leave for health treatment, leaving a total sample of 16 professionals. The locus of the study was two family health units (FHU) in the rural area and seven in the urban area of Feira de Santana, in neighborhoods located near the Universidade Estadual de Feira 
de Santana (UEFS), all linked to PET-Family Health of the UEFS. The choice of health services sought to contemplate the urban and rural areas, which enabled visualizing performance specificities in the health unit's assigned territory and those located close to the UEFS, having the verbal information obtained from ex-PET members, PET members, tutors and preceptors of PET-HEALTH regarding the establishment of professionals in these units as reference.

The functions of tutoring, preceptorship and student monitoring are described in Interministerial Ordinance No. 421, of March 3, 2010. Tutors play the role of reference advisors for professionals and/or students and are linked to higher education institutions. The preceptors are higher education professionals working in the health service with the function of supervising a specific area of activity or professional specialty, and students of undergraduate health courses develop experiences in service and research activities in the health area under the guidance of the tutor and preceptor.

\section{SELECTION CRITERIA}

The following inclusion criterion was adopted: professionals who had worked in any period as preceptors in family health units linked to PET-HEALTH for a minimum period of two years. Exclusion criteria were: workers who were on vacation, maternity leave or on leave for other reasons.

\section{Data collection}

Data collection took place in the months of March and April 2016 in the municipality of Feira de Santana, Bahia and was performed by the lead author of this study through semi-structured interviews in family health units linked to PET-HEALTH. The interviews took place in person, and were recorded in digital audio format with a recorder in a reserved place in the work environment of the participants, with prior written authorization. Privacy and the previously scheduled times for the interviews were ensured at that time.

The semi-structured interview technique was used with a script prepared by the authors, being composed of two parts: the first to record the characterization data of the professionals, the health unit location, professional training of the preceptors and their participation period in the PETHEALTH in order to outline the participants' profile. The second part presented the following guiding question of the study: What are the contributions of the Education through Work for Health Program to the preceptors of Primary Healthcare? The interviews lasted an average of 40 minutes, were recorded, stored and transcribed in full after authorization by the participants. The interviewees were free to report their experiences as preceptors. At the end of the interview, the participants had the opportunity to listen to the recordings, to authorize the transcription.

The data collection was interrupted by theoretical saturation, being considered a tool to establish the final sample number of participants in a qualitative study. The collection is completed when the information begins to be repeated in the researcher's assessment in order to avoid redundancy or repetition $^{(13)}$.

\section{DATA ANALYSIS AND PROCESSING}

The analysis method chosen is configured as content analysis due to understanding that the theories on which it is based value the subjectivities (speeches and opinions emitted in the interviews) of the study participants, and because it is the most appropriate method for the objective of the present study. This method emphasizes an analysis of communication, production of meanings and significances, and is of great importance in the scope of qualitative research. The data from the interviews were pre-analyzed with textual and thematic analysis through floating reading, constituting the corpus as per rule of pertinence, with the interviews, coding, typing, organization and classification being organized in spreadsheets. Next, the material was explored with context coding, decomposition and aggregation units, identifying the characteristics of the message and listing the manifest and latent content. The final analysis of the data was conducted through a synthesis of the results, inferences and interpretation, consisted of deepening the material obtained in the previous moments, which made it possible to apprehend the study objective through the articulation between the empirical and the theoretical aspects ${ }^{(14)}$.

\section{ETHICAL ASPECTS}

Contact with the health team began with a presentation of the researchers and the research project. Contact was also made with the Municipal Health Secretariat, together with the approval opinion of the Research Ethics Committee of the Universidade Federal da Bahia (Opinion no. 1.418.548/16), which authorized the study in the referred health units. The second step involved approaching the field of study for later application of data collection techniques according to the interest in participating in the research, proceeding with a presentation of the theme and the study objectives. The research complied with the recommendations of Resolution no. 466/12 of the National Health Council on research with human beings and followed the consolidated criteria for qualitative research reports (COREQ). Participants are identified by the letter "I", referring to Interviewee, accompanied by a random number to preserve anonymity.

\section{RESULTS}

Sixteen (16) preceptors participated in the study, most of them women, aged between 30 and 62 years. Five of them reported having participated in other areas of PET such as PET-Networks, Mental Health and Maternal-Child. Fifteen had specializations, and it is important to highlight that five of them had specializations in Public Health/ Family Health/Collective Health, while the others were specialists in different areas. Some preceptors entered an academic career, three had completed their Master's degree and one had their Doctorate degree. 
Regarding the professional category, eleven were nurses, three dental surgeons, one physical education professional and one doctor.

Based on the analysis of the preceptors' interviews, it was possible to identify and analyze the main contributions of the Education through Work for Health Program for preceptors of Primary Healthcare, which were then arranged in three categories: Expanding the perspective on health work; Experience of the teaching-learning process; and Motivation to continue and/or seek new studies.

\section{EXPANDING THE PERSPECTIVE ON HEALTH WORK}

The preceptors described one of the contributions of PET-HEALTH in this category. According to them, participation in the Program expands the perspective on health work:

(...) for me, it added up a lot, we are not just having a single view, we open a range of perspectives, it is extra motivation for work (I1).

(...) PET opened my field of vision, especially to my work as a professional (I3).

(...) wow, PET opened doors for me, showed me another reality, another look at health (I6).

(...) PET provides a new reading of the world, coexistence, learning, the bond it creates, shows how each one deals with reality and improves (19).

(...) PET brings a new look, a new clarity, sometimes in the day-to-day work we get tired, worn out, when a student arrives, it's infectious, it's very positive (I10).

(...) PET has expanded my perspective, both as a teacher and as a health service provider (I11).

(...) PET favored this, this way of looking at health education differently (I14).

\section{EXPERIENCE OF THE TEACHING-LEARNING PROCESS}

In this second category, the participants report on the daily activities developed in preceptorship in the Unified Health System (SUS) which brought them closer to the teaching-learning process and are configured as an opportunity for knowledge exchange:

(...) I learned a little with them and they with me, and I not only got involved with the works of theoretical guidance, but in the study in practice (...) (I9).

(...) PET offers us the possibility of not only adding knowledge to students who are there to understand the work process, but also to the professionals (...) (I11).

(...) PET was very enriching, the question of interdisciplinarity, of multidisciplinary activities, for the preceptor and for the student, we learn a lot from students from different courses (...) (I13).

(...) PET was a learning experience for me and for the students, because I very much believe in this issue of education, I learn and so do the students (I14).
(...) I gained new knowledge in PET, we learn a lot from the students, mainly [because] they were different areas and also reflect on our practice (I15).

\section{Motivation to CONTINUE AND/OR SEEK NEW STUDIES}

In this category, participants stated that participation in PET-HEALTH sparked interest in conducting new studies or encouraged them to continue with those already started, especially with regard to public health:

(...) PET motivated me to go back to research, then I (...) did a specialization in Public Health, then I got my Master's degree, I attribute these achievements to PET. After I entered PET, I had new motivation to go back to studying, go back to research (...) (I3).

(...) PET touched on this issue of the need, both to study and to research, I was always much more [focused] on practice, PET brought me to be studying, to be inside the university, to be researching, to publish articles (...) (I6).

(...) while the preceptor was trying to improve me, [I felt] the need to study a little bit about the students' professions (I9).

(...) I started to attend UEFS from the PET, I did my Master's degree and now I'm proceeding with the doctorate and my return, starting to return to UEFS, was because of PET(I10).

(...) PET brought me to this matter of studying, of the relationship with the student that I had not had until then, and nowadays I love to teach (...) (I2).

\section{DISCUSSION}

PET-HEALTH contributions to the preceptors include expanding their perspective on health work, the experience of the teaching-learning process and instigation/motivation to continue and/or seek new studies. The dynamic nature of the Program, together with the range of actions offered enables the preceptor to have peculiar experiences in their daily work at SUS.

The expanding of the perspective on health work was highlighted by the preceptors who participated in PETHEALTH, since they mentioned acquiring a different worldview. The preceptors come to understand the work in the health field in a multifaceted way due to the training meetings with students in the Program ${ }^{(9,15)}$.

Being with the professional in training and accompanying and being accompanied daily at the same time expands the perspective on the training path. Thus, it promotes new ways of working, teaching, learning, and producing among students and preceptors, fostering new health service workers with an expanded view of the scenario in which they work ${ }^{(7,16)}$.

In this sense, the reports by the preceptors about expanding their perspective on health work reveals that they recognize the complexity of the performance in this area. Thus, expanding the view of everyday life in the SUS enables them to search for new alternatives to work with the demands which originate from the community within the scope of health education. 
The expansion of the preceptors' vision after participating in the Program provides opportunities for workers to act in multiple directions and contributes to coping with the reality of health work, as well as in their activities as mediators of learning in the world of work. Furthermore, PET-HEALTH provided preceptors with interactions with students in the health service in order to concurrently contemplate teaching and learning. This demonstrates the countless possibilities for the development of the subjects involved in this process ${ }^{(9,15)}$.

The experience of the teaching-learning process reported by the preceptors is characterized by the dynamism and reciprocity of the actors of the Program in relation to the acquired knowledge. This scenario enables transformations in the actors involved, stimulates construction of a collective space and encourages actions of an interdisciplinary nature in Primary Healthcare ${ }^{(16)}$.

A study in the international scenario reports on the experiences of Honduran nurse preceptors and American students, in which they demonstrate that in-service learning programs must be congruent with the expectations and values of preceptors and students in order to address the needs of both according to such a reality. Thus, the teaching-learning process must be a dialogical, symmetrical and two-way path ${ }^{(17)}$.

PET-HEALTH is therefore a training opportunity for preceptors, as it is a source of unique knowledge and experiences in the teaching-learning process. There is greater integration with the students by developing the preceptorship in the daily life of the service, and above all theoretical-practical articulation in the training process during the program actions $^{(5)}$.

Cases studied in the south of Brazil on stimulating and strengthening continuing education and teaching-service-community integration found that the preceptors reflect on their world of work and the feasibility of transforming it through knowledge and practices that generate truly transformative social and political changes when receiving students in the services ${ }^{(18-19)}$.

PET-HEALTH promotes experiences of the teaching-learning process reflected in dialogue moments with the health team, with students and professors from universities. Experiences in the health service scenario, the development of clinical studies and healthcare practices enable reflection and self-assessment of professional practice ${ }^{(20)}$.

Thus, the preceptor reflects on their practices through teaching and learning, and the worker model that they have produced during the training of students. Preceptorship experiences in the space of teaching/service and community integration point to the transformation of pedagogical practices, which has impacted healthcare practice ${ }^{(21)}$.

In this logic, the experience of the teaching-learning process between preceptors and students in Primary Healthcare must be permeated by a horizontal and dialogical relationship. Furthermore, the preceptor can influence the student to develop critical thinking, reflective practice and theoretical-practical integration in the working context in the SUS, which shows a cooperative integration of knowledge for renewing health care ${ }^{(22)}$.

According to critical Freirian pedagogy, the preceptor is one who is educated in dialogue with the student in successful teaching-learning processes, who in turn also educates them when being educated. The formation process of the PET-HEALTH preceptor as a social subject occurs through action-reflection-action on their daily life. The training of the preceptor is permanent, integrated and dialogical, since the practice is constantly being done and remade ${ }^{(11,23)}$.

Motivation to continue and/or seek new studies was another contribution reported by the preceptors in this study. The search for courses/updates and even entry into graduate school reflect their recognizing the need for study, in addition to expressing a rapprochement with the university, as professional training as a preceptor is received in addition to sharing information and knowledge between preceptors, teachers and students in the integrated teaching-service-community spaces $^{(23-24)}$.

As the preceptor seeks to improve and study more, they cease to be supporting and become more participative in the training process which goes from planning to evaluating the pedagogical process. Thus, didactic-pedagogical competences are expressed in the daily life of the service through integrating and inserting the student in the health team and in the daily life of the work in SUS ${ }^{(19)}$.

However, some studies report that preceptors still do not feel adequately qualified to assume this role, as they mention the lack of specific preparation for performing the preceptor role, especially regarding the guidance of students in their daily work. In this sense, the need for a critical and reflective training process and the articulation of health, education and work according to the immersion context are emphasized. Thus, training is essential for teaching actions by preceptors in order to meet the demands arising from such a function ${ }^{(21-22,25-26)}$.

The motivation to continue and search for new studies is fundamental, especially for acting as a preceptor. The performance of this function requires didactic-pedagogical competence and not only in the domain of professional knowledge (essential for any type of training), but also pedagogical knowledge necessary to organize training actions, such as the different teaching-learning processes and the different assessment modalities ${ }^{(24,26)}$.

In this perspective, the reports of the preceptors in the present study demonstrate that they evaluate participation in PETHEALTH as a training strategy which encourages growth and professional improvement. After participating in the Program, some reported motivation to enter lato sensu and stricto sensu graduate programs, as well as the desire to return to the university for new learning and professional development ${ }^{(25,27)}$.

In view of the above, it is understood that PETHEALTH has been an important Program for preceptors, capable of promoting an expanded perspective of health, fostering experiences of teaching-learning processes and motivating the performance of relevant studies with the demands and needs present in the work reality in SUS. This process has been encouraged by integration with the service network and is in line with SUS guidelines ${ }^{(26-27)}$. 
PET-HEALTH contributions to preceptors include promoting productive teaching-learning spaces, guided by constant dialogue, an expanded worldview, collective construction and continuing education. In this process it is important to encourage reflections based on the routine of the program's activities in the SUS, and in this sense the need for the health fields, education and work to be connected to efficiently contribute to training health workers for the SUS is evident.

The impossibility of generalizing the universe of preceptors in PET-HEALTH is considered as a limitation of this study, since this study concerns a certain reality.

\section{CONCLUSION}

In the present study, it became evident that PETHEALTH provided preceptors with an expanded perspective of health work in the field of Primary Healthcare, the experience of training processes and proved to be a source of motivation for continuity and/or search for new studies. Furthermore, the Program is based on the principles of SUS, which encourages the training of personnel to work at the Primary Healthcare level.
The participation of preceptors in the Program reinforces the commitment to continuous training and research in the field by experiencing it with students from different courses, which prompts new ideas and promotes professional improvement, in addition to learning in terms of participatory construction in the SUS.

PET-HEALTH makes it possible to overcome the dichotomy between theory and practice and to produce innovative and transformative theoretical-practical knowledge through proactive, dialogical and horizontal relations between the different actors involved. Such an experience also favors developing professional skills and competencies in line with the population's social and health demands, in addition to responsibly contributing to consolidating the SUS.

This study provides a discussion on the contribution of PET-HEALTH in developing the preceptorship in the SUS in the scenario within the state of Bahia, which is similar to that observed in other Brazilian regions which develop such a program. In addition, it highlights the importance of new research on developing the preceptorship in other integrated teaching, service and community spaces.

\section{RESUMO}

Objetivo: Analisar as contribuições do Programa de Educação pelo Trabalho para Saúde aos preceptores da Atenção Primária à Saúde atuantes em unidades de saúde da família em Feira de Santana, Bahia. Método: Pesquisa qualitativa, realizada com preceptores, nos meses de março e abril de 2016, adotando como critério de inclusão preceptores que haviam atuado em unidades de saúde da família vinculadas ao Programa, por período mínimo de dois anos. Foram excluídos os trabalhadores em férias, licença-maternidade ou afastados por razões diversas. Os dados coletados foram interpretados com base na técnica de análise de conteúdo. Resultados: Foram entrevistados 16 preceptores. As contribuições do Programa aos preceptores foram as seguintes: ampliação do olhar sobre o trabalho em saúde, a vivência do processo de ensino-aprendizagem e a motivação para continuidade e busca de novos estudos. Conclusão: O Programa possibilitou aos preceptores um olhar mais ampliado sobre o trabalho em saúde no âmbito da Atenção Primária à Saúde, vivência dos processos formativos e instigação para desenvolver novos estudos, além de contribuir de forma responsável para a consolidação do Sistema Único de Saúde.

\section{DESCRITORES}

Educação em Saúde; Educação Continuada; Prática Profissional; Preceptoria; Atenção Primária à Saúde; Enfermagem de Atenção Primária.

\section{RESUMEN}

Objetivo: Analizar las contribuciones del Programa de Educación por el Trabajo para la Salud a los preceptores de la Atención Primaria de Salud actuantes en unidades de salud de la familia en Feira de Santana, Bahia. Método: Pesquisa cualitativa, realizada con preceptores, en los meses de marzo y abril de 2016, teniendo como criterio de inclusión preceptores que habían actuado en unidades de salud de la familia vinculadas al Programa, por el período mínimo de dos años. Fueron excluidos los trabajadores de vacaciones, licencia de maternidad o lejos por raciones diversas. Los datos colectados fueron interpretados con base en la técnica del análisis del contenido. Resultados: Fueron entrevistados 16 preceptores. Las contribuciones del Programa a los preceptores fueron las siguientes: ampliación del mirar acerca el trabajo en salud, la vivencia del proceso de enseñanza-aprendizaje y la motivación para dar continuidad en busca de nuevos estudios. Conclusión: El Programa he posibilitado a los preceptores un mirar más ampliado sobre el trabajo en salud en el ámbito de la Atención Primaria de Salud, vivencia de los procesos formativos y instigación para desarrollar nuevos estudios, además de contribuir de forma responsable para la consolidación de lo Sistema Único de Salud.

\section{DESCRIPTORES}

Educación em Salud; Educación Continua; Práctica Profesional; Preceptoría; Atención Primaria de Salud; Enfermería de Atención Primaria.

\section{REFERENCES}

1. Rambod M, Sharif F, Khademian Z. The impact of the preceptorship program on self-efficacy and learning outcomes in nursing students. Iran J Nurs Midwifery. 2018;23(6):444-9. DOI: http://dx.doi.org/10.4103/ijnmr.IJNMR_67_17

2. Ferreira FDC, Dantas FC, Valente GSC. Nurses' knowledge and competencies for preceptorship in the basic health unit. Rev Bras Enferm [Internet]. 2018;71 Suppl 4:1564-71. DOI: http://dx.doi.org/10.1590/0034-7167-2016-0533

3. Noro LRA, Moya JLM. O Pet-Saúde como norteador da formação em enfermagem para o Sistema Único de Saúde. Trab Educ Saúde. 2019;17(1):e0017805. https://dx.doi.org/10.1590/1981-7746-sol00178

4. Hugo L, Botma Y, Raubenheimer JE. Monitoring preceptors' supportive role: A measuring instrument for increased accountability. Nurse Educ Today. 2018;67:83-9. DOI: http://dx.doi.org/10.1016/j.nedt.2018.05.006

5. Lima PAB, Rozendo CA. Challenges and opportunities in the Pró-PET-Health preceptorship. Interface (Botucatu). 2015;19 Suppl1:779-91. DOI: http://dx.doi.org/10.1590/1807-57622014.0542 
6. Costa LS, Formozo GA. Social representations of undergraduates about the education through work for health program. Rev Bras Enferm [Internet]. 2018;71(2):244-51. DOI: http://dx.doi.org/10.1590/0034-7167-2015-0168

7. Hall KC, Diffenderfer SK, Stidham A, Mullins CM. Student and preceptor advancement in a dedicated education site: innovation in clinical education for advanced practice nurses. Nurs Educ Perspect. 2019;40(1):60-1. DOI: http://dx.doi.org/10.1097/01.NEP.0000000000000328

8. França T, Magnago C, Santos MR, Belisário SA, Silva CBG. PET-Saúde/GraduaSUS: retrospectiva, diferenciais e panorama de distribuição dos projetos. Saúde Debate. 2018;42(n.spe2):286-301. DOI: http://dx.doi.org/10.1590/0103-11042018s220

9. Flores LM, Trindade AL, Loreto DR, Unfer B, Dall'Agnol MM. Evaluation of the Education by work for Health Program PET-Health/ Surveillance Public Health by their actors. Interface (Botucatu). 2015;19(Suppl):923-30. DOI: http://dx.doi.org/10.1590/180757622014.1060

10. Silva JAM, Peduzzi M, Orchard C, Leonello VM. Interprofessional education and collaborative practice in Primary Health Care. Rev Esc Enferm USP. 2015;49 (n.spe2):16-24. DOI: http://dx.doi.org/10.1590/S0080-623420150000800003

11. Horney JA, Bamara S, Macik ML, Shehane M. EpiAssist: Service-learning in public health education. Educ Health. 2016;29:30-4. DOI: http://dx.doi.org/10.4103/1357-6283.178925

12. Bispo EPF, Tavares CHF, Tomaz JMT. Interdisciplinarity in healthcare education: the preceptor's view of family health. Interface (Botucatu). 2014;18(49):337-50. DOI: http://dx.doi.org/10.1590/1807-57622013.0158

13. Minayo MCS. Amostragem e saturação em pesquisa qualitativa: consensos e controvérsias. Rev Pesq Qual [Internet]. 2017 [citado 2018 dez. 17];5(7):1-12. Disponível em: https://editora.sepq.org.br/index.php/rpq/article/view/82/59

14. Bardin L. Análise de conteúdo. Lisboa: Edições 70; 2016.

15. Henderson A. Assisting nurses to facilitate student and new graduate learning in practice settings: what 'support' do nurses at the bedside need? Nurse Educ Pract. 2013;13(3):197-201.

16. Vihos J, Myrick F, Yonge O. Socializing for authentic caring engagement in nursing practice: nursing student moral development in preceptorship. Can J Nurs Res. 2019;51(2):63-71. DOI: https://dx.doi.org/10.1177/0844562118809258

17. Smit EM, Tremethick MJ. Preceptorship in an international setting: Honduran nurses and American nursing working together. Nurse Educ. 2014;39(2):91-5. DOI: http://dx.doi.org/10.1097/NNE.0000000000000024

18. Mitchell C, Ridgway L, Sheeran L. Preceptor education for specialty community-based nurses: a pre and post evaluation. J Contin Educ Nurs. 2018,49(3):111-8. DOI: http://dx.doi.org/10.3928/00220124-20180219-05

19. Reibnitz KS, Kloh D, Corrêa AB, Lima MM. Reorientation of nurses' training: analysis of the protagonists. Rev Gaúcha Enferm. 2016;37:e68457. DOI: http://dx.doi.org/10.1590/1983-1447.2016.esp.68457.

20. McQueen KA, Poole K, Raynak A, McQueen A. Preceptorship in a nurse practitioner program the student perspective. Nurse Educ. 2018;43(6):302-6. DOI: http://dx.doi.org/10.1097/NNE.0000000000000498

21. Silva ALF, Ribeiro MA, Paiva GM, Freitas CASL, Albuquerque IMN. Health and education by work: reflections about the PET-Health as an educational proposal for the Brazilian Health System. Interface (Botucatu). 2015;19 Suppl 1:975-84. DOI: http://dx.doi.org/10.1590/180757622014.0987

22. Freire P. Pedagogia do oprimido. 60ª ed. São Paulo: Paz e Terra; 2016.

23. Lalonde M, McGillis HL. Preceptor characteristics and the socialization outcomes of new graduate nurses during a preceptorship programme. Nurs Open. 2017;4(1):24-31. DOI: http://dx.doi.org/10.1002/nop2.58

24. Haddad AE, Cyrino EG, Batista NA. Pró-Ensino na Saúde: research on teacher education and teaching and working processes in the Brazilian National Health System (SUS), with emphasis on the reorientation of professional education in the area of health. Interface (Botucatu). 2018;22 Suppl1:1305-7. DOI: http://dx.doi.org/10.1590/1807-57622018.0493

25. Lafrance T. Exploring the intrinsic benefits of nursing preceptorship: a personal perspective. Nurse Educ Pract. 2018;33:1-3. DOI: http:// dx.doi.org/10.1016/j.nepr.2018.08.018

26. Omer TA, Suliman WA, Moola S. Roles and responsibilities of nurse preceptors: Perception of preceptors and preceptees. Nurse Educ Pract. 2016;16(1):54-9. DOI: http://dx.doi.org/10.1016/j.nepr.2015.07.005

27. Faria L, Quaresma MA, Patiño RA, Siqueira R, Lamego G. Teaching-service-community integration in practice scenarios of interdisciplinary health education: an experience of the work Education for Health Program (PET-Health) in Southern Bahia. Interface (Botucatu). 2018;22(67):1257-66. DOI: http://dx.doi.org/10.1590/1807-57622017.0226 